\title{
Maltese Language
}

National Cancer Institute

\section{Source}

National Cancer Institute. Maltese Language. NCI Thesaurus. Code C154030.

An Afro-Asiatic Semitic language that is the national language of Malta. 